\section{The Art-Based Methods in Developing Transversal Competence}

\author{
Maarika Piispanena, Merja Meriläinen ${ }^{b}$
}

\begin{tabular}{ll}
\hline Received: & 01 April 2019 \\
Revised: & 12 September 2019 \\
Accepted: & 17 September 2019 \\
ISSN: 1307-9298 \\
Copyright (C) IEJEE \\
www.iejee.com
\end{tabular}

DOI: 10.26822/iejee.2019155340

\begin{abstract}
This article describes a project called "The art based methods in developing transversal competence" funded by The Finnish National Board of Education. The article is based on the hermeneutic phenomenological approach in action research. The project developed learning environments as well as project-based learning with emphasis on the art-based methods and transversal competence approach to learning. The aim was to develop unique and communal well-being in learning. The project offered tools to strengthen teachers' professional skills to use expressive, art-based methods in different curriculum-based projects. The professional in-service training project included five contact days in six weeks divided into three periods. The expressive art work process followed the model of the expressive art work. The whole process followed the hermeneutical circle as well as the phenomenological method: expressions, reflections and sharing linked all together as a part of authentic learning experience in the context of the Finnish National Core Curriculum (2014). One of the main outcomes was that the use of the art-based methods in transversal competence increases ubiquitous well-being among teachers and pupils. Research material is based on students' diaries, experiences and anonymous feedback.
\end{abstract}

Keywords: Well-being, Transversal competence, Art-based methods, Expressive art working, Curriculum

\section{Introduction}

Well-being should never be allowed to be measured in money but it should be the right of every human being irrespective of age and wealth. However, the malaise of the children and adolescents rises more and more often reaching the headlines and the costs which go to its after-treatment make an increasingly big dent in our national economy every year as Korkman stated Helsingin Sanomat in his column 08.01.2019. Not to mention what kind of dent the malaise makes in the people themselves and their environment at a mental and physical level. Economy Nobel prize winner James Heckman raised the well-being of the children and adolescents from a preventive point of view already decades ago - according to him, the value of one coin, when focused correctly and invested through preventative measures in well-being can be even eight-fold from the productivity point of view. Heckman's investment value can certainly not be directly adapted to Finland but there is a strong seed of truth behind it: the preventive investment in well-being repays itself many times over.

The underlying values of the curriculum of basic education concretize the idea of well-being from words to action by emphasizing the significance of the specific value of the childhood. It means, that every pupil is unique and valuable as he or she is. The operation of the school has a central role from the point of view of the pupil's well-being: a pupil must feel that they are listened to and appreciated in the school community and that their learning and well-being is cared about. A pupil's well-being, growth, an affirmative self-image, learning and inclusion into society are seen to have a clear connection, for while learning, the pupils build their identity, their understanding of humanity, world view and they are finding their place in the world. At the same time, they come to understand themselves, other people, the society, the environment and the different cultures. A pupil's self-image, self-efficacy and self-esteem together influence the goals they set for their actions. (National Core Curriculum for Basic Education 2014, p. 15-16, 18.)

The changes happening around us also affect the pupils: the pupils are at the centre as the targets of the change as well as the makers and enablers of the change from the angles of knowledge and skills, growth, learning and development. The changes also have their effect on the pupils' well-being and the operation of the school. From the point of view of basic education an attempt is made to facilitate pupils' well-being and to support the changes which promote well-being in the changing situations. The mission of basic education is also to provide pupils with the tools to encounter openly the different changes and the needs brought on by the changes. Changes in the world outside the school unavoidably affect the pupils' development and well-being as well as the operation of the school. In basic education, the pupils learn to encounter pressures to change openly, to assess them critically and assume responsibility for making choices that build our future. (National Core Curriculum for Basic Education, 2014.)

Transversal competence and art-based methods in promoting individual's well-being

The society today and in the future requires from its members the competences that both cross the boundaries and link different fields of knowledge and skills at the level of the individual and of the community. The objective of transversal competence is indeed a general objective of the whole National Core Curriculum for Basic Education and it is aimed at through the each subject's definition of objectives and content areas and by connecting them. In the National Core Curriculum for Basic Education (2014, p. 20-24, p. 99-101, p. 155-158) transversal competence has been divided into seven sections: thinking and learning to learn (L1), interaction and self-expression (L2), taking care of oneself and managing

\footnotetext{
a Maarika Piispanen, Kokkola University Consortium Chydenius, Talonpojankatu 2B,67100 Kokkola, Finland E-mail: maarika.piispanen@chydenius.fi b Merja Meriläinen, Kokkola University Consortium Chydenius, Talonpojankatu 2B ,67100 Kokkola, Finland E-mail: merja.merilainen@chydenius.fi
} 
daily life (L3), multiliteracy (L4) which refers to the skill to produce and to interpret different information and texts presented by verbal, visual, auditive, numeric and kinaesthetic symbol systems, ICT competence (L5), working life competence and entrepreneurship (L6) and social participation and involvement (L7). The joint objective of these competences is to support the growth as a human being functioning as a member of the society and taking care of the sustainable development as well as to help the pupils identify their own strengths and development potential and to appreciate themselves.

The Core Curriculum for Basic Education (2014, p. 20) crystallizes that the transversal competence development is influenced not only by the contents that are worked on but also, especially by how the pupils work and how the interaction between the learner and the environment functions. In the curriculum, transversal competence has been stated as a part of the objectives for each individual subject so that each subject as an individual field already moves towards the transversal competence. However transversal competence, as its name conveys is not knowledge and skills stemming from a singular subject-orientated view. Instead, its is multidisciplinary, joining and utilizing different knowledge, skills, attitude and will to operate, leading to transversal competence. Experience of having knowledge and skills is connected to feelings of self-efficacy. Art-based methods, in turn, mean operation where an attempt is made to promote the health and well-being of an individual and to provide new points of view to approach even challenging matters through arts and culture. Recognizing and building one's own culture identity and cultural capital are an essential part of the well-being of an individual. Cultural heritage is a connection between the past, the present and the future and it contains the continuous creation and transmission of cultural significances. (Vahtikari, 2013; National Core Curriculum for Basic Education, 2014, p. 18.) The aim of art-based methods is, just as is indeed that of transversal competence, above all to strengthen self-knowledge and positive self-concept as well as analyse life, its phenomena and the relation of oneself to these. (See Känkänen 2013, p. 75.) According to Karttunen, Mansikka and Väisänen (2012, p. 57) when the art-based methods are used then at its best it starts processes which increase the experience of happiness, the feelings of being accepted and satisfaction in one's own life, which has a direct connection to the decrease in negative thoughts and for the repair of earlier unpleasant experiences. The connection of the art-based methods to the objectives of the transversal competence is very clear: both have the common aim of promoting self-knowledge and self-esteem, growth as a human being, inclusion in society and versatile sustainable development.

This article discusses in particular, how art-based methods can be used to build aim-oriented processes which strengthen the self-knowledge and self-esteem of the individual and in which the individual's core phenomena of life are examined. The angle of the discussion concentrates on the processes mentioned particularly by Karttunen, Mansikka and Väisänen (2012, p. 57) with which an attempt is made to increase well-being, happiness, the acceptance of oneself and satisfaction with one's own life. Also in the article the demonstration and experiencing of the transversal competence are examined as a part of the art-based learning processes.

During the contact days of the whole project and the time between them, the participants recorded their thoughts of their learning processes and of their working in the diary whilst receiving guidance on how to do this. The participants also received e-material after the contact day. This made it possible to utilize the used methods and ap- proaches immediately in their own work and to become better acquainted with the working process of the contact day and with the curriculum context behind it in more detail. The curriculum was examined in detail in regard to transversal competence, the aims, the contents and the evaluation and also from the point of view of expressive work in art. Each contact day was begun and concluded with the guided sharing of the experiences. Time was given for recording and sharing of experiences also whilst working. Individual diaries were given to the participants in the beginning of the in-service training and they were allowed to record their experiences in them, both independently and with guidance.

Hermeneutic phenomenological approach in action research as the research approach of the project

The art-based methods in transversal competence - project was directed at the teachers. The project's central aims were specified as providing the participants with new methods of work and pedagogical tools to develop multiliteracy, to support cultural competence and to develop social skills in the school community. Working with art was seen in the project as a tool through which aims and contents of different subjects were intertwined as multidisciplinary learning modules. Through the operation of the project the aim was to express the working culture of the curriculum of basic education and to strengthen each participant's positive idea of themselves as learners and as the producers of skills and knowledge, according to the principles of transversal competence and of the art-based approach. At the same time, the aim was to strengthen each participant's knowledge and pedagogical competence of the working culture of the curriculum, of planning, implementing and evaluating of whole learning processes, from the points of view of transversal competence, its aims and contents. The stages of expressive art work, which always include the participants' shared involvement, the working and sharing of the experiences, for its part supported the cooperation between the teachers and the sharing of expertise.

The above mentioned aims of the project set good starting points for hermeneutic action research, the leading principles of which include developing, among others, the operation or working method of the group, to carry out the study as cyclically proceeding process which contains cooperation to solve problems, and to activate the members of the research project to participate actively in the process itself. In the action research it is central to have a shared aim to have effect or to develop an area, and on the other hand the researcher's or the researchers' own active participation in the operation. (Carr \& Kemmis 1986, p. 165-166; see Suojanen, 2014.)

Suojanen (2014) connects two major trends in the action research on the basis of whether it is a question of the so-called educative operation in which it is central for the participants to educate themselves as agencies who critically evaluate themselves and their own operation, or whether it is a question of a group whose members act also partly as each others' peer coaches (peer coaching) in order to develop an area to better answer its purpose. In this research study, the trends presented by Suojanen partly overlap because the participation in the project was organized through an open application and the participants were admitted to the group in the registration order. These 18 people were willing to participate in both training themselves and to develop their work and their work communities from the point of view of the objectives of the project. This ready-set starting point and the open invitation to the in-service training served as the mapping of the starting point of the research by setting the plan of action for the training programme which every participant 
was committed to: to strengthen their skills in the use of artbased methods as enablers of the transversal competence and this way as extenders of the overall well-being, in association to oneself and the community. Because the in-service training was in the first place aimed at a teaching staff, the principle of the peer training also came true in the action research: even though the action research and the training were directed according to the aims of the project and the methods used, the experiences that were shared during and after the processes served in providing further communal and vocational development at both the individual and the community levels. This also supported the aim that was stated in the project to support the cooperation between the teachers, peer learning and the ability to develop pedagogical competence cooperatively and systematically.

In this study a phenomenological angle also was connected to the hermeneutic character, for the chosen expressive art working method naturally contains a phenomenological stance: in expressive art an experience of the process on a personal level is brought into discussion. "What do you see?" - examination uncovers significances in different levels which Betensky (1995, p. 14-17) names as the phenomenological uncovering. In relation to art and art working process it means keeping within the reality and logic of images and experiences raised by art work and processes without the interpretation, with open minds. Only after that, extending the understanding which is related to the art work and art process is begun towards one's own life. This refers to the transition back to "logic of the reality". (See Hentinen, 2010a, p. 157; Betensky, 1995).

Creating, experience and insight in strengthening well-being, knowledge and skills

In the expressive art the aim of the work isn't artistry and neither does the work itself require artistic skills from the participants. This approach responds to the aims and evaluation of the practical subjects and arts of the curriculum for basic education, where the target of the evaluation is not the knowledge and skills from the point of view of the output, but the processes involved. Even though the school and the curricula have reformed a great deal in the course of times, the old way to evaluate the output sits tightly in people's minds. This was found to be challenging also among the people who participated in the in-service training, but as a freeing process as well: it is difficult not to make evaluations of one's own or others' work but the following demand set by the curriculum helps considerably in this. The aims of the work and processes which lead to it have to be presented before the beginning of the work so that the person who participates in the art (or to any given school work) can evaluate their operation in relation to the objectives and not to the appearance or end result. This requires good knowledge of the curriculum and understanding of the working process.

The in-service training was built so that the aims and instructions of each day and stage were well explained before starting the work so that the participants were able to pay attention to the correct issues when working. It was also good to return to these aims at the stage when the participants began to evaluate their own work from the point of view of the final result - what was the objective of the work? Did the participant achieve the set aims or were they evaluating their work in some other light? We had a lot of this discussion and we experienced this as a rather important pedagogical discussion as the researchers which for its part opened the curriculum and the significance of the art work. On the basis of these discussions and experiences, the easy introduction and the transferability to one's own work of the methods experienced in the training indeed became to be one of the main categories in research results:

I can easily transfer the work in the training to the practice in

\section{my own class.}

Participation in practice gave the reassurance for my own work. Learning through the project. I was able to use many new methods of implementation for my profession.

The connection of the expressive method for sharing the experiences, interaction and peer learning is also evident in the fact that a method itself contains six different working stages which are: beginning, tuning in, art work, sharing, making connections and conclusion. These stages can also partly overlap. The working stages in question were distinguished in the working process of the five contact days but the structure of the six stages also appears when the period of in-service training is examined as a whole. At the beginning of the process, on a daily level as well as during the whole in-service training period, the significance of the beginning and tuning in were emphasized. In the middle stages of the process the emphasis was on the art work and sharing and at the end of the process the attention concentrated on making connections and conclusions.

Expressive art combines different art forms and with the help of these, the subconscious and conscious feelings and experiences are processed. When different art forms are connected to a curriculum point of view, widening the transversal competence, it is central that each contact day is planned as a whole process where the art is a tool for the widening the transversal competence and in strengthening oneself, well-being and the pedagogical competence. The following table shows as an example of how the work proceeded day by day in a process-like fashion from the perspective of the contact days.

The day-specific process supported the concept of hermeneutic circle of action research: when six stages were repeated every contact day, the participants realized the stages of progress in the process very quickly and actively shared their experiences of personal work, building the art-based process along the curriculum starting points as well as of the demonstration and strengthening of the transversal competence through the process. The final feedback, diary entries and the reflections of experiences crystallized the participants' experiences of the process well:
This training has been a journey to myself. Personal work and processing of things have been important.
It has been interesting to notice that even though I have had time and peace in the art work and I have felt that I have been resting on this course, I have still been feeling extremely tired at the end of the day. Self-processing and handling emotions are a comprehensive job, even though unifying.
I'm crying again. I have cried and laughed alternately. When you give yourself time and you do something that looks like yourself, it brings out many feelings. Sometimes I cry with joy.
The experience has been healing.
After the training day there is always a strange feeling: I almost have a bad conscience because the course has seemed like a well-being at work training and I can participate in it during my work time. On the other hand, I am always extremely tired of all the processing in a good way and at the same time I notice that my brain has worked immensely. So learning can be efficient, and even more efficient, in this way and it doesn't always have to be "blood, sweat and tears." This has been an extremely im- portant lesson for myself.

Expressive art work often includes methods which are naturally therapeutic and directional which is why it is also used in the therapeutic work and for that reason it serves objectives which strengthen well-being and self-knowledge.

This has not happened to me before that when I'm only writing a short poem it somehow sweeps me away. It required an introduction and the discussions and the interpretation of feelings ... colours ... and now I have already written many pages and there is always more text which must be written. But without process, everything that was used to tune and direct in this task, I surely would not have been able to do this. 
Table 1. The process of The art-based methods in transversal competence -project

\begin{tabular}{|c|c|c|c|c|c|}
\hline $\begin{array}{l}\text { Key stages of } \\
\text { the expressive } \\
\text { art work }\end{array}$ & $\begin{array}{l}\text { I. Pictures and words } \\
\text { expressing the } \\
\text { emotions }\end{array}$ & $\begin{array}{l}\text { II. My potrait - a } \\
\text { letter to myself }\end{array}$ & III. My dream place & $\begin{array}{l}\text { IV. I in the eyes of the art -A } \\
\text { Journey to my world }\end{array}$ & $\begin{array}{l}\text { V. I feel. Expanding the knowledge } \\
\text { together }\end{array}$ \\
\hline Beginning & $\begin{array}{l}\text { On the cottage \& } \\
\text { presenting each other } \\
\text { with the frames }\end{array}$ & $\begin{array}{l}\text { In the cottage - } \\
\text { sharing the experi- } \\
\text { ences together }\end{array}$ & $\begin{array}{l}\text { In the cottage - My } \\
\text { stomping place as } \\
\text { an adult }\end{array}$ & In the cottage: diary - work & $\begin{array}{l}\text { A house of individual learning dimen- } \\
\text { sions -a journey of mental images }\end{array}$ \\
\hline Orientation & $\begin{array}{l}\text { Leaves in the stream } \\
\text { - story }\end{array}$ & $\begin{array}{l}\text { Body Movements - } \\
\text { Pilates workout }\end{array}$ & $\begin{array}{l}\text { A pleasent moment- } \\
\text { mindset. From pic-- } \\
\text { tures to words- write } \\
\text { the lyrics to a story } \\
\text { Three circles - exercise }\end{array}$ & $\begin{array}{l}\text { A journey in the gallery of } \\
\text { character strenghts \& character } \\
\text { strengths (VIA-survey) }\end{array}$ & $\begin{array}{l}\text { The cornerstone of my knowl- } \\
\text { edge - working with the Stones as } \\
\text { orientation }\end{array}$ \\
\hline Artwork & $\begin{array}{l}\text { A windmall of } \\
\text { emotions - emotions, } \\
\text { pictures, Word, poems }\end{array}$ & $\begin{array}{l}\text { Potrait of myself- } \\
\text { drawing/painting \& } \\
\text { A letter to myself }\end{array}$ & Building a Dreamplace & $\begin{array}{l}\text { My character sthrenghts - a } \\
\text { potrait \& Two pictures of wme } \\
\text { - watercolor- \& a pointillism }\end{array}$ & $\begin{array}{l}\text { A gallry walk in the art exhibition } \\
\text { - a small group workt. Discussing } \\
\text { through the Project - My experiences }\end{array}$ \\
\hline Sharing & $\begin{array}{l}\text { Sharing the poems - A } \\
\text { flash mob show }\end{array}$ & $\begin{array}{l}\text { Reading the poem } \\
\text { to digital device, A } \\
\text { live Gallery }\end{array}$ & $\begin{array}{l}\text { The open doors of } \\
\text { dream palces - exhi- } \\
\text { bition }\end{array}$ & $\begin{array}{l}\text { A visible characther strength in } \\
\text { you - A gallery walk }\end{array}$ & $\begin{array}{l}\text { Discussing throug the Project - My } \\
\text { experiences - your experiences }\end{array}$ \\
\hline Connecting & A diary moment & $\begin{array}{l}\text { A walk in aliving gal- } \\
\text { lery: mirroring my } \\
\text { life to your story }\end{array}$ & $\begin{array}{l}\text { A diary moment \& } \\
\text { Aforism path: The } \\
\text { Gallery of Individual } \\
\text { Encounters }\end{array}$ & $\begin{array}{l}\text { Sharing the art work with char- } \\
\text { acter strenghts - reflections } \\
\text { circle }\end{array}$ & $\begin{array}{l}\text { The curriculum connections: under- } \\
\text { standing the connections between the } \\
\text { expressive art work and curriculum } \\
\text { as well as transversal competence - } \\
\text { workshop with quest colleagues }\end{array}$ \\
\hline Finishing & & $\begin{array}{l}\text { The web of appre- } \\
\text { ciative self-evalua- } \\
\text { tion - compaction }\end{array}$ & & A diary moment & $\begin{array}{l}\text { Small group work - discussions about } \\
\text { findings and experiences } \\
\text { Collecting the feedback }\end{array}$ \\
\hline
\end{tabular}

Instead of the artistry, in the expressive art work, the use of one's own creativity and the process of work as well as trusting the expressive art work process rise to the centre. Valuing the output is not included in the work. The expressive art work is a way to work multidisciplinary and even complex phenomena of life without the preset pressures. (Among others, Hentinen 2010b; Leväs \& Leväs 2000; Linnossuo 2011.)

I found myself in many others' art work.. The painting or story behind them by someone else could have been entirely my own. Incredible, how someone can write the words so well for my own feelings. It is empowering to listen to the thoughts of others.

At first it felt awful to read my own thoughts for others to hear. On the other hand, you could choose what you wanted to read or whether to read anything at all. Then I thought that I can read. It was also good to listen to my own story and to distance myself from it. Actually I am quite satisfied with my story.

At first the work seemed terribly difficult somehow when you had to find the same shades as in the picture. I just started to mix colours and to glue the pieces without thinking any more of it. And now when I look at the work from a little distance it indeed is really clear and fine. Incredible process with all its feelings: sometimes I was terribly stressed out and now the work looks quite serene and I feel like that too. Looks like I only need to trust.

Art work in deepening and widening the thoughts, feelings, knowledge, skills and the curriculum connection

When a research project proceeds on hermeneutic circle the attention becomes focused on the participants' personally experienced significances as well as on widening and deepening the understanding connected to the researchers' process of development (Laine, 2018). In this research process, the understanding of the importance of art-based methods in enabling transversal competence deepened collectively through the education process: that with art-based methods it is possible to deepen a part of individual's thinking which is emotionally significant and which is challenging, even impossible, to approach otherwise.

The study also surprised the researchers in regard to how quickly the participants began to trust the process and dealt with subjects challenging to themselves and analysed their thoughts through the process. In the discussions this came up in many ways, when the participants thought about how the art work has got them thinking about thoughts which they had not known to anticipate, to deal with or to organize.

Levine and Levine (2000, p. 23) justify this experience with the fact that art verbalizes feelings by creating the distance from them and facilitating the venting of them. Also Bardy (2002, p. 12) justifies the phenomenon by stating that art moves the mind and affects more deeply than the conscious layer to the feelings which have formed differently than the conscious layer of the mind. So it is a question of integrating the separate layers of the brain in which art work-process serves as if it is the tool: the internal feelings are expressed by creating external forms with the methods of art but also the other way round, in which case, the outputs and art which has been created awaken more feelings. The venting of feelings to create art and sharing of the art work help a better understanding of one's own experiences (Rogers 1999, p. 115-116).

As the contact days proceeded, more and more time was allocated towards the curriculum connection, in the way that by the fifth contact day the participants with their guests went through the process of each contact day and demonstrated its curriculum connection in their small groups (see, Table 1). Each small group was formed of 2-4 participants and of their guests, in which case, the number of the members of small groups was 4-6 persons. This way of working and increasing the curriculum connection to the art-based working process as the training proceeds supports the cyclical nature of action research, the concept of thinking of the hermeneutical circle and the interpretative analysis of the phenomenological approach. Spiral-like progress and gradually proceeding and completing understanding can be seen as their common features (Laine, 2018). Getting to know the exhibition and demonstrating the processes in its background to the colleagues in the small groups were seen as an important reminder and as an exercise of how to share what has been experienced in the training also later on in own work communities. The visitors acted as opponents of experiences asking specified questions of the different stages of the processes.

After viewing the exhibition and after the presentations of the processes in their background, the small groups got to examine the cards of transversal competence which contained an exact description of what each area of the transversal competence contains and means. With getting to know these, every small group went through each 
contact day's working process once more with its objectives and thought about what sectors of the transversal competence were realized according to them through the work and how. To demonstrate these findings, each small group had to move those area signs (1-7) of transversal competence by the days where each given field of competence came true in their opinion.

It was interesting to notice that every small group, without the knowledge of one another, came to the conclusion that the process of each contact day represented and promoted each of the seven areas of transversal competence. The contact days had been planned so that those central areas of transversal competence which we as educators wanted to strengthen during the contact days had been marked in the curriculum content of each day but the participants found the reasoning for the demonstration and realization of each area excellently for each contact day. From the point of view of the study, this situation showing up in the end of the education compared to beginning, where the use of art-based methods was regarded as foreign and often separate from other operation, is quite an important observation, which from the point of view of the action research also has significance in reaching the research objective. An attempt is made through the operation, experiences and reflection that have taken place during hermeneutic phenomenological action research, to have an effect on more advanced operational model taking root in the participants approaches and communities through their meta learning. (Carr \& Kemmis, 1986 , p.165; Linnansaari, 2004, p.116 -117.)

Discussion and conclusion: Consideration - increasing well-being as an objective

From the point of view of increasing ubiquitous well-being, the central main object of the project, the experiential approach was significant for the study. The connection of the expressive art work with the objectives of this project as well as to the curriculum perspective to operate as a tool for strengthening the pupil's well-being, positive self-concept, self-knowledge and interest in the different art forms and self-expression is clear: the research showed that the contribution of art work in handling the issues was experienced as an enriching and positive phenomenon while observing that art is not merely a relation to the experience of beauty but art also tells, referring to the phenomenology, the point of view of the truth. This often uncovers and clarifies an individual's own feelings and thoughts thus acting as a tool for both self-reflection and dealing with emotions. (Levine \& Levine, 2000, p.13; Paavilainen, 2003, p. 74; Betensky, 1995, p.14-17; Karttunen, Mansikka \& Väisänen 2012, p.57.)

At the beginning of the in-service training, the project's objective of transferability and implementation of methods set the researchers and educators a challenge bigger than the presuppositions because most participants experienced art work as challenging in principal: the challenges of working applied both to one's own attitude to art work and including art work as a part of the multidisciplinary processes of studying. The pedagogical objective of the training to see the methods of art work as a part of enabling transversal competence was also challenging because many of the participants felt that transversal competence becoming a concrete part of the working processes was foreign in their own work: the areas of transversal competence were known on a name basis but understanding their exact content and connecting them to the learning processes were experienced as challenging in principal. This came out in the discussions in the beginning of the project and during the last contact day when a small group stated that only with the cards of transversal competence they really understood how versatile points of view are connected to transversal competence and why they are raised in the curriculum for basic education as an embodiment of all knowledge and skills.
From the points of view of these starting points we realized as researchers how significant it is to transmit an experience to the participants, of what the art-based work means and contains, and how it can be used to promote learning according to the objectives of the curriculum for basic education without art being perceived as operation which is less valuable or unconnected to other learning. Furthermore, we realized that without the experience of increase in one's own well-being we cannot justify art work from the perspective of increasing the pupils' well-being either. Or without understanding the curriculum connection we cannot justify art work as an operation which promotes the objectives of the curriculum. To increase well-being and to understand the curriculum perspective we had to strengthen the participants' own experiences of both of these aspects. This observation resulted in the research angle being linked to the project and the research approach was selected as hermeneutic phenomenological action research, which contains the power of naturally cyclical process of proceeding connected to the experiences, reflection, interpretations and interaction of the participants.

From the research point of view we wanted to divide the effectiveness of the project into two stages. The first stage, in other words, the actual research intervention was carried out by examining art-based methods in facilitating transversal competence according to the experiences of the participants and their experiences of the increase in their personal well-being and self-understanding. This research intervention took place during the six weeks of in-service training containing five contact days in three separate periods. The time left between the contact day periods was about two weeks, during which time it was possible for the participants to implement what they had learned and experienced in the training into practice. During the contact days, the participants also kept a diary which was partly written with guidance. They used it to record their experiences during and between the contact days. These experiences and the experiences which had been gained during the working process were shared very openly during the training which for its part supported the progress of the objectives of the action research and of the project. From the point of view of the project, the other significant effect is naturally on how the participants implement what they have experienced and learned during the training to their work communities and to the pupils' school day. It has to be stated that without the first stage the second stage cannot take place either. How the second stage comes true will stay outside this research in many respects when the in-service training is scheduled within a tight time period. However, the training course was built to secure implementation so that the participants were asked to invite a colleague or a visitor from their work community to the last contact day. The participants in the training course presented the visitors their outputs and processes behind them as well as the curriculum connection and evaluated together the connection, facilitation and implementation of transversal competence in the art-based working processes. We were also allowed to hear the personal stories of many participants about how they had tried small-scale processes with their own pupils and had shared their experiences in their work communities even though the project as such did not even require this from the participants during the in-service training period.

It was particularly interesting from the researchers' point of view that even though the majority of the participants experienced the art-based methods foreign to themselves in the beginning of the in-service training, they, however, found a tool for analysing their own thoughts and feelings in the methods and in the learning processes that have been built around the methods. In this way the thought of the experiencing and increasing well-being through the work was con- 
firmed also in the participants themselves, in which case the transferability of the methods to their own work becomes more likely and meaningful.

It is noteworthy from the curriculum perspective that as researchers we had planned every working process as a multidisciplinary learning module, which had been explained fully also in the curriculum level through the objectives of different subjects, contents and the areas of the evaluation including the practical instructions and the central points of view of transversal competence to the curriculum aspect. The contact days followed the six-stage process of expressive art work, in which case the opening of the curriculum connection was left in the end of the working day and to be examined and thought about at home, so that the working process itself was allowed to begin creatively without an actual theory connection. This was regarded as an important direction particularly from the point of view of a personal experience, in which case the experience gained from working was easier to word theoretically afterwards without the theory binding the thinking in any way:

Good points in the training course were the professional guidance for practical activity and the concrete, which was justified with the help of the curriculum.

The training course was a planned wholeness in which the theory went justifiably and deliberately alongside.

The transversal competence of the curriculum opened clearly through the concrete operation when they were skilfully explained.

I was able to make, to experience and to realize how the curriculum and the transversal competence came true in everything. The connection to a curriculum, transversal competence and multidisciplinary nature appeared versatively.

The progress had been excellently designed from the activity to the theory. The training had been thought about pedagogically, pupil-centeredly and by explaining the curriculum.

At the end of the research project it is good to ask if it gave the answers to the objectives set for the project and for the tasks set for the research. In the light of the research results we can state that the participants' knowledge and skills to use art-based methods in facilitating transversal competence increased, both by experiencing and by sharing experiences together. The objectives behind the art-based methods and transversal competence to increase the individual's well-being, positive self-concept and self-efficacy as well as to give tools for handling one's own feelings became concrete to the participants also at the level of operation during the in-service training - the numerous diary entries, art work, comments and feedback we received and recorded during the training period and some of which we also collected to be shared in this research article. With these experiences and results we believe that the participants' experience of the increase in their own well-being as well as the increase in methodological and pedagogical knowledge and skills is a driving force in implementing what was experienced and learned.

\section{References}

Bardy, M. (2002). Syrjäytymisestä, taiteesta ja kehityksestä. Teoksessa I. Sava. \& M. Bardy (Toim.). Taiteellinen toiminta, elämäntarinat ja syrjäytyminen. SYREENIn Taimi-projekti 2001- 2003. Taideteollisen korkeakoulun julkaisusarja F21. Helsinki: Taideteollinen korkeakoulu, 8- 15.

Betensky, M. (1995). What Do You See? Phenomenology of Therapeutic Art Expression. London and Philadel- phia: Jessica Kingsley.

Carr W. \& Kemmis (1986). Becoming critical. Education, knowledge and action research. London: Falmer.

Hentinen, H. (2010a). Ekspressiivinen taideterapia. Teoksessa: $H$. Hentinen, M-H. Mantere \& M, Rankanen. Taideterapian perusteet. Helsinki: Kustannus Oy Duodecim. 30.

Hentinen, H. (2010b). Valmiiden töiden tarkastelu ja reflektointi. Teoksessa: H. Hentinen, $M-H$. Mantere \& M, Rankanen. Taideterapian perusteet. Helsinki: Kustannus Oy Duodecim. 157, 159, 165.

Karttunen, R.; Mansikka, N. \& Väisänen, H. (2012). Kuvassa kohdataan. Kuvataideterapeuttinentoiminta peruskoulussa. Teoksessa P-M. Hautala \& E. Honkanen (toim.) Kuva kantaa. Kuvataideterapia hoidon ja kuntoutuksen tukena. Satakunnan ammattikorkeakoulu 2012, 55-66.

Korkman, S. (2019). Tulevan hallituksen pitää panostaa lapsipolitiikkaan. Helsingin Sanomat 8.1.2019.

Känkänen, P. (2013). Taidelähtöiset menetelmät lastensuojelussa - Kohti tilaa ja kokemuksia. Terveyden ja hyvinvoinninlaitos. Helsingin yliopisto. Valtiotieteellinen tiedekunta. Sosiaalitieteidenlaitos.

Laine, T. (2018). Miten kokemusta voidaan tutkia? Fenomenologinen näkökulma. Teoksessa: R. Valli (Toim.), Ikkunoita tutkimusmetodeihin 2. Näkökulmia aloittelevalle tutkijalle tutkimuksen teoreettisiin lähtökohtiin ja analyysimenetelmiin (pp. 29-50). Jyväskylä, Finland: PS-kustannus.

Levine, S. \& Levine, E. (2000). Foundations of Expressive Arts Therapy. Great Britain: Athenaum Press, Gateshead, Tyne and Wear.

Linnansaari, H. (2004). Toimintatutkimus - tutkimus muutoksen palveluksessa. Teoksessa P. Kansanen \& K. Uusikylä (toim.) Opetuksen tutkimuksen monet menetelmät. Jyväskylä: PS-kustannus, 113-132.

Linnossuo, O. (2011). Ekspressiivisen taidetyöskentelyn menetelmäkurssi. Taidetyöskentely arjen näyttämöllä. Teoriaa, menetelmiä ja sovelluksia. Turun ammattikorkeakoulun oppimateriaaleja osa 53.

Paavilainen, M. (2003). Rafael Wardi, Valo varjossa. Hämeenlinna: Karisto Oy.

Perusopetuksen opetussuunnitelman perusteet. (2014). Opetushallitus.

Rogers, N. (1999). The creative connection: a holistic expressive arts process. Teoksessa Levine, S. \& Levine, E. (toim.) 1999. Foundations of expressive arts therapy. Theoretical and clinical perspectives. 2. painos. Lontoo: Jessica Kingsley Publishers, 113-131.

Suojanen, U. (2014). Toimintatutkimus ammatillisen kehittymisen välineenä. Luettu: 3.1.2019. https://metodix. fi/2014/05/19/suojanen-toimintatutkimus/

Vahtikari, T. (2013). World Heritage Cities between Permanence and Change. International Construction of 'Outstanding Universal Value' and Local Perceptions at Old Rauma from the 1970s to the 2000s. Väitöskirja. Tampereen yliopisto. 